\title{
A experiência religiosa: estudando depoimentos
}

\author{
Mauro Martins Amatuzzi \\ Pontifícia Universidade Católica de Campinas
}

\begin{abstract}
O presente trabalho dá continuidade a um artigo anterior que buscava uma definição de experiência religiosa em termos teóricos. Aqui se pretende chegar a uma estrutura descritiva dessa experiência a partir de depoimentos. Depois de um contato com pesquisas recentes que podem ser lidas a partir da mesma preocupação, relata-se e analisa-se um depoimento escolhido por sua riqueza de dados, buscando-se seus elementos significativos e articulando-os em uma síntese. Esses resultados são interpretados à luz do confronto com a literatura levantada neste artigo e no anterior. Conclue-se com cinco pontos descritivos deste tipo de experiência: trata-se da experiência de uma relação com o absolutamente transcendente, vivida na trama da vida cotidiana da pessoa; é uma experiência que inclui a compreensão de seu significado religioso; vivida como a experiência de uma integração do mundano com o transcendente, necessária para compreendê-lo; ocorre no interior de um processo de transformação da pessoa a partir de uma relação dialógica com os acontecimentos, e onde a própria experiência religiosa se confirma e se clarifica progressivamente; e, finalmente, é uma experiência que produz uma leveza de vida, uma valorização do humano e do natural, e um envolvimento ativo com as coisas desse mundo, sob um enfoque novo.

Palavras-chave: experiência religiosa, depoimentos, psicologia fenomenológica.
\end{abstract}

\begin{abstract}
s
The religious experience: a study of personal reports

This paper continues an earlier article searching for religious experience theoretical definition. This one aims to describe the religious experience structure, based on personal reports. Recent researches on this subject are presented. One personal report, choosen because of its richness of informations, is described and analysed, searching its significant elements and an articulated synthesis. Results are discussed confronting the literature mentioned in this article and in the earlier. The five conclusion points can be sumarysed as follows: religious experience is the experience of a relationship with the absolutly transcendent, lived in the person day-life; it includes the understanding of its religious meaning; it is lived as the experience of an integration between the mundane and the transcendet that is necessary to understant the mundane; it occurs into a process of personal changes that begins with a dialogical relationship with the day-life happenings, and in which the experience as religous becomes clarified and confirmed; and finally, it is an experience that brings some lightness in the personal life, a valorization of what is human and natural, and an active commitment with this world considered from a new perspective.
\end{abstract}

Key-words: religious experience, personal repports, phenomenological psychology.

Em um artigo anterior (Amatuzzi, 1997) estivemos buscando uma caracterização fenomenológica da experiência religiosa a partir de autores como Tomka (1997), Vaz(1986), Meslin (1993) e Buber (1984 e 1991). Aqui devemos nos basear em estudos que partem de depoimentos concretos, dando assim continuidade àquele pri-

Endereço para correspondência: Rua Luverci Pereira de Souza, 1656, Cidade Universitária, CEP 13084-031, Campinas, SP, Fone: (019) 289-2635. meiro artigo que se apresentava mais como estudo teórico. Depois de mencionarmos as principais pesquisas que poderiam ser consideradas também a partir de uma preocupação fenomenológica descritiva, faremos a leitura de um dos depoimentos colhidos por nós, escolhido por sua particular riqueza, e o discutiremos no diálogo com os autores trazidos, visando sempre uma caracterização fenomenológica desse tipo tão especial de experiência que é a religiosa. 


\section{Pesquisas recentes}

David Hay parte da abordagem de Hardy, emérito professor de zoologia na Oxford University que entre 1963 e 1965 fez conferências apresentando uma interpretação biológica do fenômeno da religião, e cuja hipótese básica é a seguinte: a consciência religiosa (religious awareness) é biologicamente natural à espécie humana, tendo se desenvolvido através do processo de seleção natural pois tem valor de subsistência para o indivíduo (Hay, 1994, p.1-2). A experiência religiosa (religious experience), para Hardy, é um conhecimento direto (direct awareness) de uma presença sagrada ou divina (...) totalmente diferente de uma crença teórica (theorietical belief), (...) [é] natural e mesmo comum, e por isso mesmo não se limita à experiência esmagadora do "mysterium tremendum et fascinans", descrita por Otto (Hay, 1994, p.2).

É interessante notar os termos destas definições. A experiência religiosa é um conhecimento direto, ou uma consciência direta, que não tem nada a ver com uma dedução racional ou uma crença teórica. O caráter direto, não inferido, anterior a processos racionais, é aqui evidenciado, e portanto seu caráter experiencial. O objeto dessa experiência é o sagrado ou o divino, portanto tomados de forma englobante. Em seguida ele afirma que essa experiência é natural e comum ao ser humano, contrariamente ao aspecto raro e excepcional, ou extraordinário, que teria segundo a caracterização de Otto. E finalmente ele diz que esta experiência ou esta consciência tem um valor de subsistência para o ser humano, ou seja, é biologicamente adaptativa.

Depois disso, Hay raciocina da seguinte forma. A hipótese de Hardy é em princípio testável. Se ela for verdadeira, a experiência religiosa: 1) não se limita às classes pobres da sociedade, como pretende a hipótese de Marx; 2) não está associada a multidões, contraria- mente à hipótese da efervescência de Durkheim; e 3) não está associada à neurose, como pretenderia Freud.

Hardy, a partir de 1960, começou a explorar sua hipótese (de que a consciência religiosa é natural na espécie humana). Divulgou pela imprensa nacional britânica um pedido de depoimentos respondendo à seguinte pergunta: "Alguma vez você já experienciou (have been aware), ou foi influenciado por uma presença ou poder, diferente de seu eu cotidiano, não importando se você o chama de Deus ou não?". Reuniu assim mais de 5000 respostas, a respeito das quais muitas pesquisas qualitativas já foram feitas, dando conta dos relatos.

Foram identificadas 8 categorias maiores de experiências relatadas. Começando pelas mais frequentes, foram essas as categorias:

1) Um tipo de acontecimento na vida da pessoa que a convence de que existe uma intenção ao acontecer (aparentemente são coincidências, mas têm um significado que fica evidente para a pessoa).

2) Experiência da presença de Deus.

3) Experiência de receber ajuda em resposta a uma prece.

4) Experiência de ser cuidado ou guiado por uma presença não chamada de Deus.

5) Experiência de estar na presença de alguém que já morreu.

6) Experiência de uma presença sagrada na natureza.

7) Experiência de uma presença do mal.

8) Experiência, por um caminho extraordinário, de que todas as coisas são "Um".

Posteriormente o estudo foi ampliado usando-se a pergunta de Hardy e mais uma, de Greeley: "Alguma vez você já sentiu como se estivesse em contato (very close) com uma força espiritual poderosa, que, de certa forma, elevasse você para fora de si mesmo?" (p.6). 
Estudos que foram feitos em torno das respostas apontam na direção oposta às da teoria do ópio (Marx), da efervescência (Durkheim), e da neurose (Freud). Sugerem também que a interpretação que as pessoas dão à própria experiência pode decorrer do medo da crítica dos outros (medo de ser considerado desequilibrado ou ignorante); o que leva também a um silenciamento.

Hay menciona a posição de Jackson segundo a qual experiências "de tipo religioso" (relatadas por pessoas normais ou esquizofrênicas) são normalmente adaptativas e ligadas à solução de problemas e à criatividade (porque, a partir de uma tensão, proporcionam uma reestruturação cognitiva). Quando essa experiência integradora ou de solução de problemas é invocada, mas falha, então aumenta a tensão cognitiva e se perpetua o ciclo de experiência "de tipo religioso", podendo ser isso a psicose, sugerindo assim que a psicose poderia ser fruto de uma experiência religiosa frustrada.

Robert Ellwood (1994) é quem faz o comentário crítico do texto de Hay. O resumo deste comentário expressa bem sua idéia:

A universalidade da experiência religiosa é afirmada por Hay. Isto traz alguma confirmação para as teses de James e Schleiermacher e desconfirma as visões de Marx, Durkheim, e Freud. Entretanto a espontaneidade de tais experiências é questionada à luz do imperativo de que toda experiência é ao mesmo tempo condicionada e formada pela cultura. O ser humano é essencialmente social e está inserido na vida cotidiana de um modo que Hay ignora. (Ellwood, 1994, p.25)

No corpo do artigo ele diz que mesmo quando uma experiência é apresentada como espontânea, é a seleção de linguagem usada para expressá-la (experiência de Deus, experiência de todas as coisas como "Um" etc) que a torna religiosa, e não outra qualidade da própria experiência; ou seja, o fato de a experiência ser religiosa ou não, dependerá da interpretação, culturalmente determinada, que brota na própria pessoa.

Sem dúvida Ellwood chama a atenção para uma questão importante e difícil: a da interpretação na própria constituição da experiência. No entanto reduzir o aspecto "religioso" da experiência às palavras usadas para expressá-la, parece nitidamente um esquecimento de seu outro polo, que é o experiencial. Experiência e consciência, ou o vivido e o interpretado, se articulam na constituição da própria experiência. Mas não podemos abandonar nenhum desses dois polos.

Tamminen (1994) propôs-se a estudar a experiência religiosa em crianças e adolescentes, com idade variando entre 7 e 20 anos.

Menciona algumas formas de se colher relatos, usadas em pesquisas:

- redação para crianças com o tema: Quando eu pensei em Deus (When I once thought about God);

- pergunta para obter relatos: Você alguma vez já teve uma experiência de Deus? Por exemplo, de sua presença, de sua ajuda, ou alguma outra coisa? (Have you ever had an experience of God, for example, his presence or his help or anything else?) (p.62).

As que foram usadas na pesquisa que ele apresenta no artigo que estamos resumindo, fo$\operatorname{ram} 2$ :

1) Você algumas vezes sentiu que Deus está próximo de você? (Have you at times felt that God is particularly close to you?) - E a solicitação que se segue a esta: Você gostaria de me contar isso, quando aconteceu, e em que situa- 
ção? (Would you like to tell me about it, when and in what situations?). - (Notemos que, em português ao menos, o verbo estando no presente, sentiu que Deus está próximo, induz uma resposta afirmativa, mais do que se o verbo estivesse no passado: sentiu que Deus esteve próximo.)

2) Você algumas vezes sentiu que Deus está guiando, dirigindo sua vida? (Have you at times felt that God is guiding, directing your life?) - E a solicitação que se segue a essa : Você gostaria de contar isso, quando e como foi? (Can you tell about it, when and how?). (p.6364) - (Aqui surge o mesmo problema do verbo no presente, e é como se estivesse pressupondo que Ele sempre guia e dirige. Talvez fosse melhor perguntar: Você alguma vez já sentiu que Deus estava orientando ou dirigindo sua vida?)

A definição de experiência religiosa usada neste seu estudo foi a seguinte: é uma experiência na qual se conecta com um senso de dependência ou ligação com Deus, o divino, eo transcendente (is an experience to which a sense of dependency on or a link with God/the divine and the transcendent is connected) (p.62-63). Mas ele afirma que esse ponto de vista é naturalmente limitado. Algumas experiências de crianças que poderiam ser classificadas como religiosas, segundo uma definição mais larga e implícita, não foram então incluídas (p.63).

Tamminen tem consciência da complexidade do fenômeno quando fala de três complicações em seu estudo:

1) o acesso que se pode ter à experiência religiosa é indireto, ou seja, se faz através do que as pessoas lembram e relatam, e em como elas a sentem e interpretam;

2) essa interpretação que os sujeitos fazem, depende de sua filosofia geral; e

3) a lembrança da experiência é determinada pelos valores presentes.
Ele menciona também as 5 dimensões da religiosidade sistematizadas por Glock \& Stark: dimensão experiencial (= experiência religiosa), dimensão ideológica (= crenças religiosas), dimensão intelectual (= conceitos com os quais é pensada), dimensão ritualística (= práticas religiosas), e dimensão consequente (= efeitos na vida diária). Certamente essas dimensões se interpenetram e, com certeza, podem valer analogicamente para qualquer ação cultural.

Algumas das principais conclusões de Tamminen foram:

- A existência de experiência religiosa tal como definida aqui, é relativamente generalizada na amostra de crianças e adolescentes finlandeses. Mas diminui na medida em que se avança da infância para a adolescência.

- As experiências de proximidade de Deus foram principalmente relatadas em situações de solidão, medo e emergenciais (perigo, doença), ou seja, de direção por parte de Deus, em situações de perigo e outras dificuldades. Foram ambas também relacionadas com escolhas morais e ações, e também com oração atendida.

- Na média, as meninas relataram com mais frequência experiências religiosas, e com algumas diferenças detectáveis, no conteúdo e na forma do relato, em relação aos meninos.

Note-se que o tipo de resultado visado tanto por Hay (1994) como Tamminen (1994) nestas pesquisas não é descritivo, isto é, eles não pretenderam aqui explanar a natureza da experiência, mas sim tirar conclusões específicas a respeito dela, comparando situações através de um estudo estatístico. No entanto elas podem ser lidas como o fizemos aqui, relacionadas a nossa preocupação. Nosso estudo pretende ser simplesmente descritivo, e só nessa medida, elucidativo. 


\section{Meu encontro com Lídia}

De vários depoimentos colhidos, alguns por escrito e outros gravados em audio, escolhemos um deles, o de Lídia (todos os nomes são fictícios) para relatar aqui, por ser o mais rico e complexo. Para esses depoimentos, os participantes foram primeiro convidados a colaborar com uma pesquisa sobre experiência religiosa. A partir daí houve uma entrevista não diretiva ativa (cf.Mucchielli, 1991, p.30-33), semi-estruturada em torno de alguns temas, os quais podem se expressos com as perguntas:

1) Como foi sua maior experiência de Deus?

2) Como foram outros momentos marcantes de sua experiência de Deus?

3) Como é sua experiência atual de Deus? Se possível dê exemplos.

4) Pense nos seus momentos especiais de oração ou meditação. Como você se prepara para esses momentos? Como você se coloca na presença de Deus, ou como você O invoca?

5) Qual é sua experiência de prática religiosa?

Lídia é uma senhora de 60 anos na época da entrevista, casada, com filhos e netos, descendente de imigrantes italianos e escravos negros. Freqüentou somente os primeiros anos da escola oficial, mas gosta muito de ler. Teve uma educação católica tradicional, daquelas em que tudo é pecado, como ela mesma diz. Com o passar do tempo, foi adquirindo uma visão diferente das coisas. Exerceu funções de liderança na comunidade católica local, que ajudou a criar, mas hoje está um pouco mais afastada (está voltando) por conta de uma cirurgia importante à qual teve que se submeter, e que a deixou de cama por muito tempo.

Tive um primeiro encontro com ela em sua casa (em um bairro periférico de uma cidade grande do interior de São Paulo), para conversarmos sobre sua experiência religiosa, em maio de 1997. Ela não quis gravar nada. Disse que queria conversar antes e depois ela gravaria, se eu quisesse.

Foi uma conversa fascinante para mim. Admirei muito sua capacidade de comunicar toda uma experiência de vida, e mesmo uma sabedoria, daquele modo simples, no meio daquelas histórias pessoais de suas narrativas. O que ela me contou foram fatos que falavam da "mão de Deus" em sua vida, principalmente como proteção transcendente, ou uma presença na qual ela confia.

Como ela se dispôs a gravar depois dessa primeira conversa, voltei lá uma segunda vez alguns dias depois. Pouco a pouco ela foi se desinibindo diante do gravador, e acrescentou detalhes interessantes à primeira entrevista.

A transcrição integral da entrevista ficaria muito longa para os limites desse artigo. Transcreveremos apenas trechos mais significativos, que possam depois orientar a leitura que faremos.

Aquilo que ela considerou como sendo uma de suas maiores experiências de Deus, $o$ caso da tempestade, ocorreu quando ela era uma jovem de 15 anos. Toda sua família trabalhava numa fazenda. Com os outros familiares, ela estava justamente numa lavoura de café neste dia.

Era num morro. Então nós estava naquele elevado, e as ruas de café começa numa baixada e subia, vinha no alto do morro. E meu irmão chegou e disse que vinha vindo uma tempestade. E a minha irmã mais veIha falou: vamos embora? Então todo mundo pegou o que tinha e saiu correndo. E eu fiquei mais patrás porque nós tinha um irmão mais pequeno, ele devia ter uns seis anos. Todo mundo saiu e foi embora correndo, e eu fiquei com ele patrás. 
Quando nós chegamos no alto do morro, nós encontramos com a tempestade. Aquele vento vinha assim como se fosse um redemunho, ele levantava a terra do chão. E lá era areia, era pedregulho, e aquilo era jogado no rosto da gente. Dojeito que o vento vinha, jogava no rosto da gente, junto com a chuva.

Ela havia ficado para trás cuidando do irmãozinho.

$E$ de repente meu irmão começou a se afogar. E eu não sabia o que fazer. Pra acudir ele eu também comecei a me afogar.

(Vi que havia ali um toco) que $t i$ nha sido comido pelo fogo, um casqueiro; o resto era uma casca. Então eu puxei ele naquele tronco. E a altura do tronco protegia a gente do vento.

E nesse momento eu disse pra Nossa Senhora, falei: Minha Nossa Senhora, nós vamos morrer aqui, e os outros não vão nem ficar sabendo. Porque não via jeito. Mas no mesmo momento a tempestade sumiu. Ficou assim aquela chuvinha levinha. E eue ele pudemos sair e ir embora pra nossa casa.

Mas para mim foi como se Nossa Senhora tivesse, naquele momento, pegado a tempestade e tirado ela do nosso lado, e a gente pode se ver livre. Porque pelo que estava acontecendo ia morrer eu e ele naquele lugar, porque perdemos o fôlego. Como ia respirar? Foi uma coisa dificil.

Eu sempre guardei isso comigo.

Eu sempre digo isso, assim, quando a gente chama Nossa Senho- $r a$, qualquer santo da proteção da gente, eles atende! Se a gente está em perigo, eles atende sim.

E foi um milagre, pra mim foi um milagre, porque a chuva passou na hora.

E ela comentou ainda:

A gente era acostumado a enfrentar temporal, era acostumado a enfrentar tempestade, mas a gente sempre escondia atrás dum pé de café, atrás de uma árvore. Mas aquele dia nós encontramos com a tempestade de frente. Então não tinha como se esconder. $E$ providencialmente apareceu aquele toco. É engraçado que a gente sempre passava lá e eu nunca tinha prestado atenção... o jeito que ele era. E aquele dia ele foi providencial.

Depois ela contou o caso do administrador, que aconteceu um ou dois anos depois, em uma outra fazenda.

...Então o fiscal me colocou para trabalhar numa horta da fazenda, porque a gente dependia desse trabalho da gente para sobreviver... E ele me colocou lá para trabalhar, $e$ eu ficava lá sozinha...

De repente eu vi o administrador vindo do meu lado. Sabe quando a gente vê a pessoa assim, parece que a gente tem um pressentimento que alguma coisa não está certo. E ele chegou e disse assim que eu estava trabalhando sentada. Eu disse pra ele: é claro, o moranguinho é rasteiro. Não tem como trabalhar de pé. Tem que trabalhar abaixado, senta- 
do. E ai eu falei pra ele - ele chamava José - eu falei pra ele: né, Seu José, a gente tem que trabalhar assim. E ele me disse assim: José por que? Me chama de Zézinho! E eu disse pra ele: Não, a minha mãe sempre me ensinou assim, que os mais velhos a gente precisa respeitar. E se eu falar para o Senhor, Zézinho, somos iguais. E eu falando Seu José, o Sr. precisa me respeitar porque eu estou lhe respeitando... Ele ficou muito desconcertado e saiu.

\section{E comentou:}

Depois que passou aquele momento, eu não entendia aonde eu tinha arrumado aquela resposta pra dar pra ele. E eu consegui me sair muito bem, né? Mas eu acho assim que sempre é Deus, o anjo da guarda que está protegendo a gente. Porque a gente que é mulher, pobre, negra, é muito visado. Porque normalmente as pessoas achava assim que por um punhado de moeda a gente ia fazer qualquer coisa que eles quisesse, né? Mas eu sempre tive a proteção de Deus.

\section{E mais adiante:}

... a gente tinha que estar sempre atenta a tudo que acontecia, senão a gente podia cair numa cilada.

Em seguida conversamos sobre o caso da operação espiritual, que aconteceu há uns 17 anos. Conta como esteve passando muito mal, com dores, sem poder andar muito sem ter que se sentar. Depois de algumas indicações, conseguiu arranjar um médico. Tomou injeções, fez exames. E ela continua contando:
O dia que eu fui pegar os resultados, deu que eu tinha um quisto no rim. O médico disse que precisaria acompanhar para saber se ia precisar operar. Mas ele achava que precisava operar. Então fui fazendo um tratamento, mas eu continuava tendo problema.

E nesse periodo, uma minha irmã teve aqui. E ela não me deu explicação; pediu que eu escrevesse alguma coisa, o que eu sentia, no papel. E eu escrevi. Ela colocou um endereço, e colocou no correio. Daí uns dias, acho que uns 8 dias, eu recebi a resposta. Era dum Centro Espirita do Rio, que agora eu esqueci o nome... Eles me dizia na carta que marcaram uma data, era um sábado, que era pra mim trocar de roupa, trocar a cama, deixar tudo limpinho, ficar no quarto sozinha na penumbra, e evitar baruIho. E que eu ia ser atendida. Eles ia me operar.

Se eu não acredito e não desacredito, eu não sou pessoa de ficar abusando. Só que eu tenho muito medo dessas coisa, porque eu não entendo. Ai eu fiz tudo que eles tinham pedido. OAntônio (marido de Lídia) $e$ a minha sogra ficou aqui na sala, eles tava vendo a televisão bem baixinha. De repente eu tive a impressão que eu vi um vulto entrar no quarto. Assim fosse uma sombra. E depois eu não me lembro mais nada; eu dormi. No outro dia eu amanheci tão ruim; eu tinha a boca ruim, eu tinha mal estar; eu só queria deitar. No lugar da dor que eu tinha no rim, eu tinha como se fosse uma mão que me segurava naquele local. Eeupassei o dia todo mo- 
vimentando porque a casa estava cheia de visita. E eu não podia falar nada pra ninguém, né, que eu estava me sentindo mal... Mas passou.

Aí eu ia, de 8, 15 dias, eu fazia exames pra ver como que estava, se estava regredindo, né? Pra minha surpresa eu fui fazer os exames, não deu mais nada. O médico mesmo falou pra mim que tinha desaparecido, e ele não sabia como. Eu peguei o raio $X$, levei para o médico do posto; ele também olhou, falou pra mim: não tem mais nada, não tem com que você se preocupar; desapareceu o que você tinha. Então eu só posso acreditar que foi por intermédio deles, né?, que isso desapareceu. Porque com o remédio não ia desaparecer de uma hora pra outra, né? Mas desapareceu, eu fiquei bem, não precisei passar por cirurgia nenhuma.

\section{E ela explica:}

Por intermédio de outras pessoas, Ele nos socorre, né? Eu acho que é pra mostrar pra gente que todos são filhos de Deus, né? Não é porque não são católicos, porque são de um outro credo... que eu acho que toda fé leva a Deus. Que se eles fazem isso com fé, eles conseguem ajudar outras pessoas como me ajudaram.

Depois disso, conversamos sobre como são seus momentos de oração. E ela começou dizendo:

...pode parecer engraçado para você, mas eu não sou uma pessoa que vivo rezando. ... um momento que eu tenho vontade de voltar pra
Deus, normalmente eu canto. Eu tenho um salmo que eu gosto muito dele, ele me fala muito! ... quero cantar um pedacinho pra você. Ele é assim...

E começou a cantar, com uma voz muito bonita. E seu canto dizia:

"Teu nome é, Senhor, maravilhoso; por todo universo conhecido; até por crianças pequeninas; tua força domina o inimigo. Olhando pro céu que tu fizeste, pra lua, pras estrela tão bonita, indago o lugar que cabe ao homem; mais vale aos teus olhos a sua vida."

Normalmente se eu tenho vontade de rezar, eu estou cantando um salmo. E este é o meu predileto. Agora quando eu chego na igreja, em qualquer lugar, num momento que eu preciso falar com Deus, eu aprendi um modo, com uma pessoa que me contou um caso, uma história que me marcou muito. ...eu acho que pra Deus a gente não precisa muito diálogo. Ele nos entende, porque foi ele que nos fez. Então ele nos conhece. Não é verdade? Normalmente eu tenho alguma coisa para pedir. Mas eu sempre digo: Senhor, eu estou aqui... O Senhor me fez, me criou, me deu a vida, e sou sua filha; então estou aqui na sua presença. Eu acho que só isso basta.

E ela foi introduzindo um outro assunto, dizendo:

Eu acho que ele me conhece... Tanto que, você vê, ele me tirou do fundo do poço. Porque essa cirurgia me levou no fundo do poço. 
E então ela começou a contar sua última cirurgia, que praticamente mudou sua vida. Relata uma longa história, que passa por muito médicos, muitas guias, muitos exames, e questões financeiras. Até que

$$
\begin{aligned}
& \text {....descobriram que eu tinha um } \\
& \text { tumor... }
\end{aligned}
$$

E aqui sua voz tremeu.

Os exames continuaram, agora em internações, ...e eles não chegavam a uma conclusão... sobre a natureza do que tinha.

Por fim era um tumor raro, entre a mama e a costela. Ela foi internada para cirurgia, num grande hospital. O médico chegou bastante tempo depois, e solicitou uma reunião da família, dizendo que

... eu precisava assinar um documento porque eles achavam que ia ter que tirar o meu braço.

E aqui Lídia fez uma pausa mais longa, para segurar um choro. Depois continuou:

... Talvez? Perguntaram ao médico. E ele disse: "Não. É quase que certo. Então você precisa assinar um documento, porque nós precisamos da autorização sua e da família”. Olha ... sabe o que que é o chão abrir $e$ voce entrar dentro?

Mandaram um rapazinho conversar comigo, não sei, eu fiquei com pena dele. Ele chegou e falou pra mim que ele era psiquiatra. $E$ eu entendi que ele era pediatra. (Risos). Ai eu pensei assim comigo: Mandaramesse pediatra falar comigo o quê? Ai ele começou a conversar, perguntou pra mim como é que eu estava reagindo. Eu falei: Como que você acha que eu posso reagir? Eu estou na eminência de perder o meu braço. Ai ele perguntou se eu dormia. Falei: Olha, eu durmo. Quando eu acordo eu tenho a impressão que estou saindo de um pesadelo, mas eu durmo. Então ele me disse se eu queria remédio para dormir. Falei: Não, não quero. Porque não vai resolver a minha situação. Então não quero remédio. E ele falou pra mim assim: Você ficou desesperada com a notícia? Eu falei: Porquê? Se eu sair gritando, resolve? Se eu sair gritando resolve, então vou começar gritar. E ele não soube o que falar. Ai ele me disse assim..., se eu tinha trabalhado com pessoas desse tipo de trabalho social. Eu falei: Não, não fiz esse tipo de trabalho. Ai ele disse assim: Olha, é uma pena, porque amanhã eu estou indo embora. Mas eu gostaria muito de acompanhar a senhora nesse momento, porque eu fiquei admirado de ver a sua reação.

$\mathrm{Na}$ véspera... eu levava as coisa na brincadeira, sabe? Pra ninguém... Porque olha, o Antônio chorava, as criança chorava, eles não sabia como falar pra minha sogra. Você já pensou...

Falou para o marido:

Se eles tirarem meu braço, eu quero saber aonde eles enterraram. Olha, pra você ver a minha preocupação. Eu quero saber onde eles enterraram. Porque afinal de contas é uma parte minha, né? (voz embargada).

E então conta como uma pessoa do hospital veio conversar com ela, distrair, dizer que 
ia dar tudo certo. Até fizeram juntas alguma oração. - Sua cirurgia demorou mais de 10 horas, ela ficou depois 7 dias na U.T.I. Não foi necessário tirar seu braço, mas ela perdeu alguns movimentos, e ficou com marcas no tórax.

Comentando seu encontro com a enfermeira com quem havia conversado e orado, ela diz:

Só depois ... quando eu voltei pro quarto, eu descobri que ela era uma evangélica. Então ela ia no meu quarto de noite ... e falava pra mim: Vamo orar? Ai, eu gosto de orar junto cocê desde o primeiro dia que eu te vi. Então eu acho assim que, não importa, Deus é um só, né? Eu sou evangélica, você é católica, mas o nosso Deus é o mesmo, não é? Então vamos rezar pra ele. Eu não te falei para você que ele ia te tirar dessa dificuldade? E te tirou, não tirou?

No dia que eu sai da cirurgia... então quando eu comecei a voltar a si, as enfermeiras iam aonde eu estava e falavam pra mim assim: Olha! Abre o olho! Não precisou tirar seu braço. Olha pra você ver que maravilha.

Mas ela não pode sequer prestar atenção pois sentia muita dor ... na mão.

Eu tinha uma dor! que eu não queria saber de braço, eu não queria saber de nada. Eu tinha uma dor desesperada! Eles tinham passado uma faixa na minha mão (e ela me mostra um sinal na mão, e outro no braço), $e$ esta faixa estava cortando a minha mão. E a dor era tão latejante, que eu não queria saber de nada, eu queria que aliviasse aquela dor.
E ela conta então seu desespero para se comunicar com as pessoas, estando com tubos na boca e o braço preso, para lhes dizer daquela dor insuportável na mão. Falando rapidamente, ela diz:

Eu comecei a arrancar os fios, porque estava tudo entubada, né. Eu arrancava, arrancava, arrancava. Falava: Elas vão ter que descobrir o que que eu estou tentando mostrar $e$ elas não entende.

Por fim, depois daquela luta com as enfermeiras, o médico descobre que a faixa estava cortando a mão dela. Então:

...Eudormi, porque eu acho que eu não dormia por causa da dor, né. Eu dormi e acordei no outro dia. Ai que eu fui dar conta de mim, que não tinha tirado o braço, e a dor tinha acalmado, né, a dor tinha passado.

Depois de mais detalhes de seu esforço para se comunicar, ela conclui:

Olha..., se o Dr. ... não descobre, eu ia perder a mão. ... Teve que fazer curativo (na mão).... Se ele não visse ... tinha cortado todos os nervos da mão...

\section{E ela comenta:}

Olha ... por quanta coisa eu passei! Então eu falo assim: Gente, eu estive no fundo do poço. Mas sabe ... eu só imaginava: será que Deus está fazendo comigo como ele fez com Jó? Você sabe a história de Jó...? 
Ela conta a história de Jó, e depois continua:

E eu imaginava naqueles dias assim: será que Deus está pensando em fazer comigo o que fez com Jó? Tentando deixar que o demônio descubra minha paciência até onde vai? Mas se é isso que ele quer, seja feita sua vontade. E eu sai do fundo do poço, né.

A propósito do apoio que recebeu dos amigos da comunidade, ela diz:

... e descobri uma coisa maravilhosa! Quantos amigos eu tenho. Amigos verdadeiros! Então acho que de todas coisa ruim a gente tira uma coisa boa, né? Nada de mau neste mundo é tão mau. Ele tem um lado bom. E com essa doença minha descobrio que esse povofez pra mim. Me carregaram no colo até que eu pudesse ficar de pé. ... Se eu tivesse dinheiro, eu ia ficar imaginando assim: será que eles não estão atrás do meu dinheiro? Mas como eu não tenho dinheiro nenhum...

... Pra você descobrir o quanto a tua fé é grande, você tem que estar lá no fundo do poço. E tem que descobrir que você vai ter que sair de lá de algum modo.

Então era assim, viu Mauro. Quando eu estava com dor, eu fazia escândalo, eu gritava. Porque eu sei que se não fizer escândalo não te socorrem. ... Mas quando a dor passava, eu brincava, eu contava piada, eu dava risada. ... Porque chorar não adianta nada, né?

Eu sei que passei por tudo isso... Por qual motivo eu não sei, porque pra gente não interessa saber o que que Ele quer da gente, né? Interessa você cumprir e acabou. Essaé a minha função.

Perguntei então qual era sua prática na comunidade religiosa atual.

Olha ... eu estou voltando. Não posso dizer pra você que já voltei. Eu estou voltando com passos medidos, né? Porque eu tenho muita deficiência, eu fico muito cansada, sabe? Então eu estou voltando devagarinho.

Mas eu vou falar uma coisa pra você. Quando a gente está participando a gente não consegue ver as coisa. Porque você está dentro. Mas quando você está fora é que você descobre as coisa bonita que fazem, as coisa bonita que as pessoa consegue passar. Quando eu comecei a voltar pra igreja, eu fui na missa um dia, e cheguei lá eles estavam fazendo uma apresentação, tinha que apresentar a comunidade. E o que que eles fizeram? Eles fizeram uma hóstia. Bem grande. E cortaram ela em três pedaços. E ai cada pessoa entrou com um pedaço daquela hóstia, e em frente o altar eles uniram ela. Olha, eu achei aquilo tão bonito! Eu achei que aquela pessoa que teve aquela idéia, foi uma coisa maravilhosa. Porque eu acho que a comunidade é isso. Tem que unir todas as partes pra ela ter sentido, né?

A partir daqui ela conta o quanto ela esteve envolvida desde o começo da comunidade, tendo sido coordenadora geral e de várias equipes tam- 
bém. E como a comunidade se formou como um desmembramento de outra, mais distante.

...Eu não fui eleita coordenadora, não. Eu botei a cara! Porque alguém tinha que fazer, né?...

E contou, com detalhes, casos dos primeiros tempos, dificuldades de conseguir as coisas, as idéias que tinha para solucionar os problemas que surgiam, os contatos com os diversos padres e com o bispo, as realizações, a dureza que foi, a confusão para arranjar tábuas para fazer os bancos da primeira sala de catequese (que era em sua própria casa), o trabalho de carregar esses bancos e as outras coisas para as celebrações no salão, e depois trazer tudo de volta... mas também o prazer de fazer tudo isso.

Olha, Mauro, eu não arrependo de nada que eu fiz. Se precisasse... agora eu não tenho mais pique, né?... Mas se precisasse eu faria tudo de novo.

E num olhar de conjunto, ela comentou:

Só quem caminhou com a gente é que sabe a dureza que foi. Mas a gente tinha força, a gente tinha saúde. Mais do que isso, a gente tinha prazer de estar fazendo aquilo. Porque lembra que eu falei pra você que as vez eu ficava chateada? Eu subia ali em cima, ficava lá com as crianças e ficava imaginando assim: meu Deus! Será que eu nasci só pra isso? Pracozinhar, lavar roupa, passar roupa, fazer comida? Não, eu acho que não nasci pra isso não. Então o meu espírito já tinha vontade de fazer alguma coisa. E de repente surgiu a oportunidade. Eu estava falando pra você da catequese, que Seu Tarcísio pedia pessoas pra dar catecismo, e um dia eu fui timidamente falar pra ele que eu gostaria de dar catecismo. E aí foi o meu primeiro passo. Ede repente eu estou aqui hoje.

A gente vive numa comunidade, e eu acho que a comunidade precisa da gente. E uma coisa, Mauro, que eu aprendi, e eu falo isso pras pessoas. Eu era... Eu ficava admirada de minha reação... Se eu estivesse conversando com você eu não sabia o que falar. Eu era tímida. Então as vezes as pessoas me achava orgulhosa, porque a minha irmã mais velha é espontânea. Eu não; eu ia conversar com as pessoas e não sabia o que falar. Parece que tudo que eu ia falar estava errado. Então ficava assim trancada. E... de repente eu descobri que eu... podia ser gente, né? Que eu acho que é isso que a gente tem que descobrir: que pode ser gente. Então eu falo assim: olha, eu consegui me libertar daquela timidez, consegui fazer um trabalho, graças a Deus.

E... eu falo pras pessoas da comunidade, que eu tenho uma coisa importante: todo mundo é importante. De repente as pessoas aparece aqui, e ele tem vontade de participar. Se vocês não der oportunidade, ele não vai participar. Se tem o que ele pode fazer, não faça nada você; deixa ele fazer. Porque vai ter o dia em que não tem quem faça e você vai ter que fazer. Que você vai estar sempre ali. Então eu acho que sempre tem que ter um lugar pra alguém. E ninguém é demais. Pra todo mundo tem um serviço. A gente só tem que descobrir o 
que a pessoa pode fazer, aonde ele é importante. Porque não existe serviço importante, não é, Mauro? O que existe é você que é importante. Porque não é o serviço que faz você, é você que faz o serviço. Não é? Então eu acho assim, olha: o importante é a pessoa que pode fazer aquele serviço, porque o serviço não faz o homem. $O$ homem é que faz o serviço. E isso a gente aprende na luta, né? Porque como a gente foi muito espezinhado, passado pra trás, doeu muito, né? E hoje a gente sabe que não faça isso, porque dói. Doeu pra mim, vai doer pros outros.

\section{Uma visão do todo da entrevista}

Lídia teve uma educação religiosa considerada por ela mesma como tradicional dentro do catolicismo, daquelas em que tudo era pecado. Isso como que dá um ponto de partida do caminho que ela vai narrar. Com o passar do tempo, foi adquirindo uma visão diferente das coisas. Ela supera o catolicismo de tipo tradicional, superava a idéia de uma religião onde tudo é pecado, uma religiosidade austera, de proibições, ameaças e culpas, em direção a uma religiosidade de mais liberdade, e de possibilidade de ser o que se é. E... de repente eu descobrique eu... podia ser gente, né? E a sua experiência religiosa foi o processo de descoberta de sua própria humanidade.

Neste caminho um momento importante foi o de sua abertura para uma vivência comunitária mais ativa. Ela descobriu e assumiu que sua vida não precisava ficar restrita à casa, ao tanque e à cozinha, que isso não a satisfazia. Meu Deus! Será que eu nasci só pra isso? Pra cozinhar, lavar roupa, passar roupa, fazer comida? Não, eu acho que não nasci pra isso não. Então o meu espírito já tinha vontade de fazer alguma coisa. E de repente surgiu a oportunidade. $\mathrm{O}$ começo foi se oferecer para trabalhar com catequese de crianças: Aí foi o meu primeiro passo. Mas depois seu envolvimento foi cada vez mais profundo a ponto de ela se tornar uma líder na comunidade e no bairro. $E$ de repente eu estou aqui hoje. (...) Eu botei a cara! Porque alguém tinha que fazer, né? E a avaliação que ela faz hoje, muito tempo depois do começo, é extremamente positiva. Para ela tudo valeu a pena. Eu não arrependo de nada que eu fiz. Se precisasse... eu faria tudo de novo.

\section{Os elementos significativos da experiência religiosa}

Quando perguntei sobre sua "maior experiência de Deus", o que Lídia contou foi $o$ caso da tempestade. Ela gritou para Nossa Senhora e foi atendida. No mesmo momento a tempestade sumiu. O que aparece primeiro é o caráter extraordinário do acontecimento. E foi um milagre, pra mim foi um milagre, porque a chuva passou na hora.

Nessa ocasião ela era uma mocinha de 15 anos, portanto numa fase inicial de todo o caminho que fará depois, e com a visão das coisas que tinha na época. Esta visão, de algum modo, ainda se faz presente na memória e em sua forma de ver as coisas até hoje. Lídia não a nega. Quando a gente chama Nossa Senhora, qualquer santo da proteção da gente, eles atende! Se a gente está em perigo, eles atende sim. É a experiência de uma proteção extraordinária. Mas ela diz: Para mim foi como se Nossa Senhora tivesse naquele momento pegado a tempestade e tirado ela do nosso lado. É essa maneira de ver que faz mais sentido para ela, que dá conta de forma mais global do que está acontecendo, e que portanto integra sua experiência. 
Depois, num segundo comentário do episódio, o extraordinário já não é mais o cessar da tempestade, mas a presença providencial de um toco de árvore. $E$ providencialmente apareceu aquele toco. É engraçado que a gente sempre passava lá e eu nunca tinha prestado atenção... o jeito que ele era. E aquele dia ele foi providencial. O caráter extraordinário aqui, está na simples presença de um objeto anteriormente despercebido. E Lídia passa naturalmente de um detalhe a outro, como se estivesse falando de uma só coisa. É que tanto o cessar da tempestade como o aparecimento do toco, são manifestações de uma mesma coisa: a proteção especial de Deus (pela mediação de Nossa Senhora ou qualquer santo ou anjo da proteção). A experiência de Deus é pois, mais uma experiência da proteção especial, pessoalmente sentida, e da qual aspectos admiráveis (miraculosos, providenciais) são apenas manifestações.

Consideremos ainda que esse primeiro episódio relatado não foi uma experiência de conversão, no sentido de algo totalmente novo e que mudou sua vida. Foi uma experiência marcante, mas que se inseria numa vida que já era religiosa. O sentido expresso de ter sido uma experiência de Deus cabe nesse contexto, e por ter sido marcante, de alguma forma, confirma o valor do religioso em sua vida.

É interessante notar, finalmente, a forma como Lídia constrói sua oração ou seu grito de socorro. Literalmente ela não pede nada, mas simplesmente expõe a situação: Minha Nossa Senhora, nós vamos morrer aqui, e os outros não vão nem ficar sabendo. O pedido é implícito. É como se dissesse somente: olhe nossa situação! Isso pressupõe uma relação de confiança. Deus ou a santa é que sabem a solução ou têm o poder. O pedido é, na verdade, um simples colocar-se nas mãos do transcendente, uma reafirmação, quase familiar, de uma relação cotidiana de dependência e confiança, a propósito de uma situação de necessidade. Essa mesma forma de orar é a que aparece quando ela comenta, depois, sua experiência de oração.

No caso do administrador a ameaça que pairava sobre ela era uma tentação. Ela poderia ter "se prostituído" (foi a palavra que usou na primeira entrevista, não gravada). Ela conseguiu se preservar também por proteção de Deus. E o lado admirável nessa situação foi que ela, sendo tímida e não sabendo responder bem às pessoas, apesar disso teve a resposta adeqüada, graças à qual se livrou do assédio do administrador. Eu não entendia aonde eu tinha arrumado aquela resposta pra dar pra ele. E eu consegui me sair muito bem, né? Mas eu acho assim que sempre é Deus, o anjo da guarda que está protegendo a gente. Porque a gente que é mulher, pobre, negra, é muito visado. Ela se saiu bem nessa situação, e em outras parecidas nessa época de sua vida, livrando-se de assédios que implicavam até em risco de vida algumas vezes. Eu cheguei a ser tão perseguida, que eu cheguei correr risco de vida na rua. Naquela época. Hoje, olhando para trás, ela afirma: Eu sempre tive a proteção de Deus. Mais uma vez, sua experiência religiosa é a de uma proteção especial de Deus, constante, que se mostra de forma admirável, em certas situações de ameaça ou perigo.

Antes da conversa gravada, ela havia me contado também o caso da janela quebrada: como não tinham dinheiro para consertar um grande buraco em sua janela, a vedação foi feita com jornal, e apesar de sua casa estar em rua movimentada, não houve nenhum assalto ou roubo. Esse caso confirma o que dissemos acima. O admirável foi o fato de não ter acontecido algo ruim. Foi dessa forma que se manifestou a proteção de Deus.

Essa mesma proteção se mostra por caminhos surpreendentes no caso da operação espiritual. Foi pelas mãos de pessoas de outra religião, também instrumentos de Deus, que ela 
foi curada. Por intermédio de outras pessoas, Ele nos socorre, né? Eu acho que é pra mostrar pra gente que todos são filhos de Deus, né? Não é porque não são católicos, porque são de um outro credo... que eu acho que toda fé leva a Deus. Que se eles fazem isso com fé, eles conseguem ajudar outras pessoas como me ajudaram.

É interessante notar aqui o relacionamento de Lídia com religiões diferentes da sua. Elas também são caminhos, seus fiéis são fillhos de Deus e instrumentos de sua vontade. Ela tem um profundo respeito, dentro de seu temor, por isso. Se eu não acredito e não desacredito, eu não sou pessoa de ficar abusando. Só que eu tenho muito medo dessas coisa, porque eu não entendo. Ai eu fiz tudo que eles tinham pedido. Uma atitude semelhante vai aparecer quando ela ora com a enfermeira protestante no hospital. Embora ela seja católica praticante, sua experiência religiosa ultrapassa barreiras rígidas de uma igreja fechada.

Conversando sobre seus momentos especiais de estar na presença de Deus, momentos de oração, ela diz que não é uma pessoa que vive rezando, lendo a Bíblia, ou rezando o terço antes de dormir. O apoio de sua experiência religiosa não são fórmulas ou práticas específicas $\mathrm{e}$ freqüentes. Ela chegou mesmo a deixar outra pessoa meio escandalizada com isso. É mais algo como uma atitude, que se espalha pela vida, como um sentimento de ser ou estar nesta relação com o transcendente: então eu acho que pra Deus a gente não precisa muito diálogo. Ele nos entende, porque foi ele que nos fez. Então ele nos conhece.

No entanto, ela tem seus momentos de oração também. Quando tenho vontade de me voltar para Deus, normalmente eu canto. É uma expressão poética, corporal, livre de utilidades imediatas. Assim também a outra forma que ela às vezes usa. Mas eu sempre digo: Senhor, eu estou aqui... O Senhor me fez, me criou, me deu a vida, e sou sua filha; então estou aqui na sua presença. Eu acho que só isso basta. Como no caso da tempestade, não há um pedido específico, mas um recordar-se da relação de criatura com seu criador, mas que é, ao mesmo tempo, um colocar-se confiante e dependente na presença deste criador.

O salmo preferido por ela também não contém um pedido. É mais um olhar contemplativo para as belezas de Deus ou do mundo, à luz do religioso, e mesmo para o lugar especial que o ser humano ocupa nesse mundo. Teu nome é, Senhor, maravilhoso; por todo universo conhecido. E: Olhando pro céu que tu fizeste, pra lua, pras estrela tão bonita, indago o lugar que cabe ao homem; mais vale aos teus olhos a sua vida. Olhar para o divino a faz descobrir o humano.

Para Lídia, a oração é a consciência de uma presença, transcendente e real, expressando-se de acordo com o momento (momento de necessidade, momento de contemplação). Sob esse aspecto a experiência religiosa é a própria vida humana, vivida na relação com essa presença.

O que resume sua experiência religiosa a propósito de sua recente cirurgia, é esta expressão: Ele me tirou do fundo do poço. Humanamente foi uma experiência radical de perda dos apoios da vida: Olha, Mauro, sabe o que que é o chão abrir e você entrar dentro?

Mas eis como ela interpreta a situação vivida: será que Deus está pensando em fazer comigo o que fez com Jó? Tentando deixar que o demônio descubra minha paciência até onde vai? Mas se é isso que ele quer, seja feita sua vontade. E eu sai do fundo do poço, né. E em outro momento: Pra você descobrir o quanto a tua fé é grande, você tem que estar lá no fundo do poço.

$\mathrm{O}$ que corresponde à vivência da relação com Deus como uma presença protetora, do lado dela é um seja feita sua vontade. Em outro momento ela comenta: Eu sei que passei por 
tudo isso...Por qual motivo eu não sei, porque pra gente não interessa saber o que que Ele quer da gente, né? Interessa você cumprir $e$ acabou. Essa é a minha função.

Consciência da relação e entregar-se. Mas isso implica num enfrentar a situação. $E$ tem que descobrir que você vai ter que sair de lá, do fundo do poço, de algum modo. Então era assim: Quando eu estava com dor, eu fazia escândalo, eu gritava. Porque eu sei que se não fizer escândalo não te socorrem. Então eu fazia um bruta tropé, e eles me socorria... Mas quando a dor passava, eu brincava, eu contava piada, eu dava risada.

Apesar da dramaticidade da situação, havia, paradoxalmente, uma certa leveza. Eu levava as coisa na brincadeira, sabe? Ou: Se eu sair gritando, resolve? Se eu sair gritando resolve, então vou começar gritar. E ele, o psiquiatra que viera para consolar e dar apoio, não soube o que falar. Ele percebeu algo diferente em Lídia. Ela se lembra que ele lhe disse: eu fiquei admirado de ver a sua reação.

Um outro ponto importante na experiência dessa cirurgia é que o corpo é muito valorizado por Lídia, e serve de guia, muitas vezes, para o que ela deve fazer. Isso corresponde ao fato de que muitas vezes para ela orar é cantar. Essa valorização do corpo aparece, por exemplo, quando ela, emocionada, diz: Se eles tirarem meu braço, eu quero saber aonde eles enterraram. Olha, pra você ver a minha preocupação. Eu quero saber onde eles enterraram. Porque afinal de contas é uma parte minha, né? Em outro momento, quando ela ia contar uma coisa tão importante como o fato de que não foi necessário perder o braço, e de como isso foi uma proteção de Deus, ela se lembra de outro detalhe: a dor que sentia na mão, e a necessidade de reagir para aliviar. Eu não queria saber de braço, eu não queria saber de nada. Eu tinha uma dor desesperada! Eles tinham passado uma faixa na minha mão e esta faixa estava cortando a minha mão... eu queria que aliviasse aquela dor. Só depois de resolvido o problema, e de ela ter dormido até o outro dia, é que ela foi tratar de ver o braço que estava lá. Ai que eu fui dar conta de mim, que não tinha tirado o braço, e a dor tinha acalmado, né, a dor tinha passado. Ou seja, no caso de Lídia, uma valorização do corpo faz parte dessa leveza conseqüente à entrega.

Finalmente, também fez parte desta experiência, essa coisa tão gratificante de se sentir no meio de uma rede afetiva. Descobri uma coisa maravilhosa! Quantos amigos eu tenho. Amigos verdadeiros! ... Me carregaram no colo até que eu pudesse ficar de pé. E refletindo sobre essa amizade, ela conclui: É só por amor que você pode fazer tudo isso, né? Que não tem dinheiro que pague. É como se aquela presença que está no âmago da experiência religiosa, se estendesse para a solidariedade humana. A experiência afetiva daquela amizade tão concreta, era ao mesmo tempo a experiência de um amor que tem sua fonte no mesmo Deus em quem ela e os amigos confiam e a quem se entregam. É alguma coisa que não é mensurável em termos financeiros: não tem preço.

A narrativa dessa situação recente permite-nos, então, descrever alguns outros pontos de sua experiência religiosa: vivência de uma relação com um Deus protetor, como já tínhamos visto, mas de seu lado um entregar-se na fé. E que isso não a retirava da luta para uma espécie de conformismo, mas pelo contrário, a liberava para um enfrentamento das situações. E, nesse enfrentamento, muitas vezes o seu corpo lhe dava as pistas necessárias. E nele também a solidariedade humana se transfigurava. Algumas dessas coisas vão se confirmar com a narrativa de sua experiência comunitária.

É no meio da conversa sobre a experiência de Deus que ela conta de seu envolvimento mais ativo com a comunidade. Isso se deu a par- 
tir de uma tomada de consciência da insatisfação com sua vidinha fechada dentro de casa. $E u$ acho que não nasci pra isso não. Então o meu espirito já tinha vontade de fazer alguma coisa. Uma insatisfação de vida, um espírito que já tinha vontade e um agir. No dinamismo de sua experiência religiosa, ela responde com atos concretos.

$\mathrm{O}$ início foi tímido. Mas depois sua vida se ampliou de forma inimaginável. Eu fui timidamente falar pra ele que eu gostaria de dar catecismo. E ai foi o meu primeiro passo. E de repente eu estou aqui hoje! Há uma iniciativa pessoal para o primeiro passo. $\mathrm{E}$ isso se repete a cada nova etapa. Eu não fui eleita coordenadora, não. Eu botei a cara! Porque alguém tinha que fazer, né?

Há uma insatisfação, uma confiança em si, a descoberta de um serviço, uma iniciativa tímida e um envolvimento progressivo. E o resultado: eu não arrependo de nada que eu fiz. Se precisasse eu faria tudo de novo. O combustível de toda essa caminhada, além da força e saúde da juventude, foi: a gente tinha prazer de estar fazendo aquilo.

E ela foi descobrindo uma série de coisas. Comunidade é isso: tem que unir todas as partes pra ela ter sentido. - A gente vive numa comunidade, e eu acho que a comunidade precisa da gente. - Todo mundo é importante ... ninguém é demais. ... só tem que descobrir ... aonde ele é importante.

Mas essas descobertas externas, eram possíveis graças a uma descoberta interna. $E u$ era tímida. ... Parece que tudo que eu ia falar estava errado. Então ficava assim trancada. E... de repente eu descobri que eu... podia ser gente, né?... eu consegui me libertar daquela timidez, consegui fazer um trabalho, graças a Deus. Assim como ela descobriu que sua vida anterior estava insatisfatória e que ela não havia nascido para isso, assim também descobriu que sua timidez podia ser vencida. $E$ isso foi o início de um grande trabalho.

Como ela foi descobrindo essas coisas? No enfrentamento. A propósito da descoberta da importância das pessoas ela diz: E isso a gente aprende na luta, né? Porque como a gente foi muito espezinhado, passado pra trás, doeu muito, né? E hoje a gente sabe que não faça isso, porque dói. Doeu pra mim, vai doer pros outros.

A grande lição que resume tudo: eu acho que é isso que a gente tem que descobrir: que pode ser gente. Foi isso que ela descobriu e é isso que ela quer para os outros.

Em que essa descoberta do humano é uma experiência religiosa? Sua religião poderia ter se desenvolvido no sentido de uma maior separação entre Deus ou o mundo do transcendente, e o mundo real em que vivemos. Mas na verdade, parece ter sido o contrário: ela é que foi a inspiração desse caminho de integração. É a partir de sua fé que Lídia diz que o que a gente tem que descobrir é que pode ser gente e em ligação com isso, que todo mundo é importante.

Mostrei para Lídia a transcrição de seu depoimento e esta busca de elementos significativos com um esboço de síntese. Sua reação foi dizer que eu havia tornado mais claro o que ela tinha dito de forma mais embaralhada. Não propôs nenhuma mudança específica, espantou-se de dizer muitos "né", sentiu-se mais à vontade com o uso de nomes fictícios para proteger uma certa confidencialidade e consentiu com o uso do depoimento para a pesquisa.

\section{Pontos para uma síntese}

Qual a estrutura da experiência religiosa que se revela no relato da experiência de Lídia? A busca de elementos significativos foi permitindo chegarmos a algumas características dessa experiência. Foi feita, então, uma segunda leitura dessa busca, selecionando as expressões mais características. Essas expressões selecio- 
nadas foram usadas para construir frases completas e mais ou menos independentes (sempre levando em conta o depoimento como um todo e o objeto da pesquisa). Nessas frases, que são as que se seguem, as expressões selecionadas estão grifadas.

1) O caráter extraordinário do acontecimento vivido faz parte da experiência.

2) Uma maneira de ver, que evidencia um sentido, integra essa experiência.

3) É a experiência de uma proteção especial de Deus, pessoalmente sentida.

4) Essa proteção pode ter aspectos admiráveis, miraculosos (inexplicáveis pelos caminhos normais) ou providenciais (portadores de uma intenção, mas pode também estar inserida na vida cotidiana, sem o caráter miraculoso).

5) $\mathrm{O}$ acontecimento relatado insere-se numa vida que já era religiosa e a confirma.

6) A experiência inclui a reafirmação de uma relação cotidiana de dependência e confiança para com Deus, a propósito de uma situação de necessidade.

7) É a experiência de uma proteção especial de Deus, constante, que se mostra de forma admirável, em certas situações de ameaça ou perigo. 8) A experiência ultrapassa barreiras rígidas de uma igreja fechada, isto é, o que nela se manifesta não se deixa limitar pelo contexto de uma instituição religiosa, mesmo que seja aquela com a qual a pessoa se identifica. A experiência religiosa é pessoal e não institucional.

9) É como uma atitude ou sentimento de ser ou estar nesta relação com o transcendente (a propósito da oração).

10) Há um recordar-se da relação de criatura com seu criador, que é ao mesmo tempo um colocar-se confiante e dependente na presença deste criador (a propósito da oração).

11) É a atualização da consciência de uma presença, transcendente e real, expressando-se de acordo com a natureza do momento (a propósito da oração).

12) A experiência religiosa é a própria vida humana, vivida na relação com essa presença, enquanto passível de uma tomada de consciência.

13) É a própria perda dos apoios humanos $d a$ vida, mantendo contudo um apoio mais radical, na relação vivida com Deus.

14) É a consciência da relação com Deus, como único apoio em momentos de risco, aliada a um entregar-se confiante, e implicando em seguida num novo modo de enfrentar a situação.

15) Essa experiência, na medida em que assumida, produz, como efeito próprio, uma certa leveza de vida, um certo humor.

16) Faz parte dessa leveza uma valorização do corpo, passando ele a ser assumido como guia ou pista para o que se deve fazer, ou como expressão do que se passa ou dos compromissos da pessoa.

17) Também faz parte dessa leveza um sentir-se no meio de uma rede afetiva de pessoas, fundamentada exatamente numa mesma comunhão, a qual transfigura a percepção dessa rede de solidariedade e afeto.

18) Juntamente com o lado ativo pessoal de um entregar-se na fé-confiança, existe um novo empenho no enfrentamento das situações. $(=14)$

19) Da dinâmica do entregar-se da fé, e em conseqüência disso, na vida do dia a dia, existem respostas com atos concretos.

20) Essa dinâmica pode se dar como num ciclo: há uma insatisfação pessoal, uma confiança em si, a descoberta de um serviço, uma iniciativa tímida e um envolvimento progressivo.

21) Aquela conseqüente leveza de vida, então toma a forma de prazer.

22) A dinâmica da experiência religiosa transportada para a vida cotidiana, leva à descoberta da própria humanidade (é isso que a gente tem que descobrir: que pode ser gente) e, a partir 
daí, da comunidade humana concreta e do valor das pessoas.

23) A dinâmica da experiência religiosa é a dinâmica de uma integração entre o mundo do transcendente e o mundo real, cotidiano, em que vivemos.

Esta lista de frases dá uma idéia da experiência numa linguagem ainda intermediária entre a própria linguagem de Lídia e a formulação de uma estrutura mais geral. A passagem para o nível mais geral pode ser feita se, a propósito desses 23 pontos, nos perguntarmos de que estrutura de experiência eles são a manifestação particular (sobre síntese particular e síntese geral, cf. Giorgi, 1985). Desse procedimento resultaram os seguintes pontos:

1) A experiência religiosa é basicamente a experiência de uma relação com o absolutamente transcendente (que, para Lídia é Deus, o Criador e Senhor de todas as coisas), porém enquanto presença atual que se manifesta em acontecimentos, mas que é também presença constante, manifestando-se na consciência de uma dependência absoluta (que Lídia expressa como consciência de ser criatura, dependente de seu Criador e Senhor) e que pode ser evocada a qualquer momento, numa atitude de oração.

No caso de Lídia, essa presença e relação às vezes toma o aspecto de algo extraordinário, miraculoso, que exige mais que as explicações naturais, mas também pode ser percebida pelo aspecto providencial do que ocorre, enquanto portador de uma intenção, ou, mais simplesmente ainda, como consciência de ser criatura e viver na relação com o Criador. Lígia também admite intermediários, mensageiros ou instrumentos, os anjos e santos que invocamos, ou mesmo outras pessoas de quem Deus se utiliza. 2) Essa relação com Deus tem como que dois lados: experiência de uma presença e de uma resposta humana. Mas não são dois momentos separados, pois é na resposta que a presença é assumida, mesmo sendo ela resposta a algo que se manifesta.

Para Lídia a experiência da presença de Deus (ou algum de seus mensageiros) se apresenta sob a forma da experiência de uma proteção especial sentida pessoalmente, ou seja, é a experiência de uma presença protetora. E a resposta humana se configura como sendo uma entrega absoluta e confiante.

A experiência da presença, para ela, não se dá apenas no âmbito da instituição religiosa de fé comum, ou sob seu patrocínio oficial, digamos assim. Ela pode ser sentida, ou experimentada, fora da comunidade de identificação religiosa, junto a pessoas de outra religião ou outra confissão, que são vistas então, como instrumentos dessa presença. O que significa dizer que é mais uma experiência pessoal do que institucional.

Além disso, para Lídia, essa presença se manifesta preferencialmente em situações de necessidade, carência, ameaça ou perigo.

Quanto ao lado de resposta humana, para Lídia, é inicialmente um abandono completo ao poder de Deus, um entregar-se, um cumprir, um seja feita sua vontade, porém ativo, como ato ou disposição da pessoa.

3) Mas esse abandono acaba gerando depois um enfrentamento ativo das situações, no clima da confiança da entrega. Ou seja, passa a ser uma outra forma de relação com o mundo, que não tem nada de passividade ou conformismo. No caso de Lídia isso fica claro desde o momento em que ela puxa seu irmãozinho para perto do toco, na tempestade, e se manifesta também pela forma como ela reagiu face aos problemas particulares de sua última cirurgia, ou face às exigências e questões da vida comunitária, por exemplo. A palavra que para ela o expressa é luta.

4) Essa experiência é diretamente relacionada com uma certa leveza de vida que dela decorre, 
que no caso de Lídia assume aspectos de alegria, humor, prazer, uso flexível do próprio corpo como pista do que deve ser feito ou expressão dos estados de espírito, e de uma espécie de transfiguração do olhar que permite uma outra compreensão das coisas.

5) É uma experiência que inclui a compreensão de seu significado religioso, para aquele que a vivencia. Isto é, faz parte do experienciado a compreensão (espontânea, anterior a elaborações mais sofisticadas), de que se está vivenciando uma relação especial com o transcendente ou, como diria Buber, com o absolutamente independente de nós.

Para Lídia, a experiência inclui o tipo de olhar novo, que depois acaba se espalhando para outros momentos da vida.

Teoricamente essa inclusão da compreensão do significado implica na possibilidade de recusa. Só se pode dar conta plenamente da experiência a partir de seu interior, o que significa que a passagem é um salto. Contudo, fenomenologicamente se deve afirmar que existe um dar-se conta real a partir de seu interior.

6) Existe uma dinâmica processual na experiência, que a aprofunda e confirma. Quer dizer, não é apenas uma experiência que existe como acontecimento isolado, mas toma consistência no interior de uma vida que já era de certa forma atravessada pela vivência de uma relação (no caso de Lídia, a experiência toma consistência no interior de uma vida que já era religiosa, se bem que de uma forma ainda tradicional), e por outro lado desencadeia novos passos nessa mesma vida (respostas pessoais e novos discernimentos), confirmando e purificando o significado da relação anterior. Ou seja, a experiência religiosa não é apenas um acontecimento, mas também todo um processo, que se confirma e se aprofunda.

7) Nesse processo há uma aceitação e potencialização de si próprio, como ser humano, uma valorização da pessoa e da comunidade, na solidariedade, através de uma integração com o divino. No caso de Lídia foi a descoberta, no contexto de toda sua experiência religiosa enquanto processo, de que se pode ser gente, seu envolvimento progressivo com a comunidade, $\mathrm{e}$ seu compromisso crescente com o valor das pessoas para além dos serviços. Esse encontro com o humano se dá justamente no clima de uma integração do divino no mundo.

8) Podemos destacar esse último aspecto como um ponto à parte: a experiência religiosa como processo é uma experiência de integração entre $o$ divino e o mundano, sendo que este adquire novo sentido a partir daquele, e um sentido que manifesta sua própria natureza mais profunda. No caso de Lídia, isso não chega a ser verbalizado ou tematizado plenamente, mas é o que se manifesta em vários momentos de seu relato em que os episódios são vividos em si mesmos, enquanto mundanos, mas ao mesmo tempo são entendidos sob uma luz nova, compreendidos em um contexto mais abrangente.

9) Fazem parte da experiência religiosa enquanto processo as experiências de provação, confirmação, novas descobertas e novos posicionamentos. No caso de Lídia as provações que ela menciona ocorreram a propósito de situações de falência de apoios humanos ou de insatisfações pessoais, as confirmações se deram por ter ela saido do fundo do poço ou tomado iniciativas transformadoras, as novas descobertas se referem ao valor pessoal no contexto da comunidade, e os novos posicionamentos se referem ao progressivo envolvimento dela com a vida ou a comunidade, por exemplo.

\section{Discussão e conclusões}

Vamos dividir essa discussão em três momentos. 


\section{1) Uma aproximação entre o relato de Lídia e os autores citados}

Resulta dessa aproximação uma confirmação mútua em muitos pontos, e alguns enriquecimentos que a experiência de Lídia pode trazer.

À luz das considerações de Tomka sobre a religião nos tempos pré e pós modernos (Tomka, 1997), a experiência de Lídia parece ser a de uma religiosidade que evolui de um contexto mais tradicional, ligado a uma sociedade rural, para um contexto pós-moderno, posicionando-se aí a partir de um polo interior de integração, baseado numa experiência relacional cada vez mais inserida neste mundo. No seu caso esse movimento pode ter acompanhado uma migração do campo para a cidade, mas que não se perdeu numa atitude de recusa do mundo, ou fechamento em um mundo privado pessoal ou sectário. Há uma aceitação do mundo tal como é, e uma constante tomada de posição face a ele a partir de uma fonte pessoal de integração, forjada em experiências de relação.

Um importante ponto de virada parece ter sido o momento em que Lídia reagiu diante de uma vida fechada, que não a podia satisfazer mais, tomou uma decisão ainda sem saber muito bem a totalidade das conseqüências, e iniciou timidamente uma caminhada no seio da comunidade, que foi evoluindo e envolvendo sua pessoa cada vez mais. E isso é típico da terceira atitude mencionada por Tomka. E é na trama dessa caminhada que foram tomando consistência real suas relações com Deus, o totalmente independente de nós, e que no entanto fornece um sentido último à vida. É interessante comparar esse ponto de virada, uma decisão, com o fato que Lídia relatou com sendo uma de suas maiores experiências de Deus: o caso da tempestade. São bem diferentes, e no entanto para ela existe uma continuidade entre um e outro: para ela é o mesmo Deus que se faz presente protegendo, num caso, e libertando o poder pessoal por caminhos viáveis, no outro.

O relato de Lídia segue um pouco o percurso de sua própria vida, da adolescência para a idade adulta e depois para a meia idade. $\mathrm{E}$ as diversas fases de sua experiência são valorizadas no contexto desse processo. Talvez por isso, à luz do conjunto, pudemos ir além do milagroso do primeiro caso, e aí encontrar também uma outra coisa, essencial, que vai se manifestando aos poucos: a experiência de uma relação com uma presença. É isso que aparece no caso da tempestade, em sua oração, na provação de sua última doença, e que justifica também seu dinamismo atuante na comunidade, e que acaba despontando como a relação com um sentido radical. Esse é um ponto central que, de formas diferentes, foi enfatizado tanto por Meslin, como por Vaz e Buber.

$\mathrm{O}$ aspecto abrumador (obscuro e talvez tenebroso) da experiência religiosa para Buber e Otto, talvez se aproxime mais daquilo que Vaz chama de experiência do Sagrado. Esse aspecto não é muito evidente nos relatos de Lídia. Predomina aí a confiança da fé. E embora essa confiança seja posta à prova em situações difíceis, ela vai se confirmando. O humor e a alegria estão mais presentes no relato de Lídia do que a gravidade ou a obscuridade.

Quanto ao aspecto de evolução da experiência, o relato de Lídia é bastante claro: a religiosidade da adolescente de 15 anos e da Senhora de 60 são bem diferentes embora haja um eixo comum ao longo do qual ela se desenvolve. E o fato de isso não ter sido tematizado através de conceitos novos, só reforça o fato de que a evolução não é exatamente nem primeiramente no plano das idéias, e sim no plano propriamente experiencial, de fé, de compreensão da presença, na presença. É claro que isso poderá ter depois, sua conceitualização. Mas ela é sempre secundária, derivada, subsidiária em re- 
lação à experiência, por mais necessária e funcional que possa vir a ser.

O relato de Lídia ilustra também o fato de a experiência religiosa não poder se confundir com a experiência mágica, gnóstica ou da subjetivização (ou talvez psicologização?) da fé, conforme nos fala Buber (1984). Não há controle, pelo contrário, há um abandono, uma entrega incondicional. No entanto daí nasce um enfrentamento ativo posterior, muito diferente do controle mágico, e que nossa análise de Meslin e Buber não evidenciou. Não há tampouco uma tentativa de desvendar os mistérios divinos, transformando-os em algo a nosso alcance. Pelo contrário: a pureza da experiência aponta na direção de um respeito pela alteridade. E também não há, na estrutura para a qual aponta, o excesso de reflexão que a psicologiza.

Quanto à hipótese básica de Hardy, retomada por Hay (1994), segundo a qual a consciência religiosa é natural à espécie humana e tem valor de subsistência para o indivíduo, ela é ilustrada pela experiência de Lídia pelo menos em sua segunda parte. Foi essa consciência que lhe abriu os caminhos de um desenvolvimento pessoal. E se o caráter "natural" dessa experiência for entendido como não terrível ou esmagador, como sugerem certas descrições, também Lídia o ilustra.

Quanto às categorias criadas a partir dos relatos colhidos por Hardy (citadas por Hay, 1994), as três primeiras (acontecimento percebido como portador de uma intenção; experiência da presença de Deus; e de receber ajuda em resposta a uma prece) são certamente ilustradas pela experiência de Lídia. O sentimento de ser cuidado ou guiado por uma presença não chamada de Deus (quarta categoria de Hardy) também pode ser ilustrado pelo "caso do administrador", mas com a diferença que para Lídia essa presença é a de Deus; ela não tem nenhuma dúvida disso. Para ela, no entanto, a experiência tem um caráter mais indireto, embora imediato.

A definição de experiência religiosa que orientou o estudo de Tamminen (1994) (experiência na qual se conecta com um senso de dependência ou de ligação com Deus, o divino, e o transcendente), também serviu como orientação para a coleta de nossos depoimentos. Ela pode ser uma definição limitada, como comenta Tamminen. De fato, não é imediata a ligação que Lídia faz de seu envolvimento comunitário com a experiência de Deus; isso surge como uma compreensão mais profunda do conjunto de seu relato.

Lídia também ilustra a conclusão de Tamminen, segundo a qual muitas das experiências religiosas relatadas estão contextualizadas em situações de emergência, perigo, doença, dificuldades.

2) A estrutura levantada a partir da experiência de Lidia em confronto com as afirmações de outros estudiosos

A idéia aqui é que a estrutura que foi evidenciada a partir do relato de Lídia, curiosamente permite uma espécie de síntese dos autores mencionados em nosso primeiro artigo, para além das diferenças de perspectiva.

A relação com o transcendente enquanto presença atual, é enfatizada tanto por Meslin como por Buber, e é um dos aspectos centrais nas pesquisas de Hay e Tamminen. Na verdade, é o centro da experiência religiosa. Porém essa relação é bastante diferente de qualquer outra reiação intramundana que possamos ter. Daí porque dizer somente isso, não é suficiente para descrevê-la. E nossos autores sabem bem disso.

O segundo ponto de nossa síntese a partir do relato de Lídia, era justamente que essa relação tem dois aspectos, que são como que dois lados de uma moeda, e que não podem ser separados: experiência de uma presença e, ao mes- 
mo tempo, da resposta humana. Isso quer dizer que a presença só se revela plenamente como tal, na resposta. Meslin deixa isso muito claro. Para Buber é o caráter abrumador da experiência. Há uma entrega. E é ela que permite o desdobramento do revelado e é nesse desdobramento que ele manifesta toda sua característica.

$\mathrm{Na}$ verdade as coisas aqui são bastante complexas, e nem mesmo essa última formulação é perfeita, pois pode ser entendida como se a resposta humana não tivesse nada a ver com a presença que se manifesta, o que não é o caso. Faz parte da descrição fenomenológica da experiência religiosa, o fato de ela ser vivida como um dom. E isso também é evidenciado por Meslin, e pela consciência aguda da alteridade que ela implica, em Buber. Poderíamos aproximar isso de nosso quinto ponto: essa experiência inclui a compreensão de seu significado. Todo processo é vivido como unidade, como uma única experiência, mesmo que para bem explicá-lo, devamos descrever momentos diferentes.

Nosso sexto ponto o explicita ainda mais: existe uma dinâmica processual na experiência, que a aprofunda e confirma. E a essa luz poderíamos dizer que esse aprofundamento e confirmação já estão presentes em seu núcleo primeiro, independentemente do fato de que isso venha a se desdobrar ainda mais posteriormente. Isso tem a ver com a depuração da experiência religiosa de que falávamos em relação a Buber.

Talvez pudéssemos dizer que a experiência religiosa tem dois polos que variam em intensidade. Quanto mais intenso seu polo objetivo, de revelação, mais apagado fica seu polo subjetivo, de entrega; porém não inexistente. $\mathrm{E}$ quanto mais intenso seu lado subjetivo de entrega, mais apagado fica seu lado de revelação; porém não inexistente.

Os outros pontos se referem mais às conseqüências, porém, em termos da dinâmica processual, ainda devemos dizer que essas conseqüências não lhe são totalmente exteriores. Recordemos pois, esses pontos.

O quarto deles fala de uma certa leveza de vida, que se segue quase como um alívio ou paz. $\mathrm{O}$ terceiro e o sétimo estão relacionados com uma certa transfiguração ativa da vida: há uma redescoberta e potencialização de si e da comunidade, e bem poderíamos dizer, da natureza (e isso está relacionado com o olhar novo, que aparece no quinto ponto) e a partir daí, um enfrentamento ativo das situações, para além da entrega ou abandono inicial, e no mesmo clima da confiança.

O oitavo ponto, experiência de integração entre o mundano e o divino, pode ser entendido também como um aspecto da transfiguração conseqüente. O sentido último do mundano se dá pelo divino. Mas isso mostra também que não podemos dizer que tal visão nova seja uma conseqüência externa à experiência original: a própria experiência original pode ser exatamente essa descoberta desse sentido último. E aqui o paralelo mais claro é com Vaz: a experiência de Deus como experiência do Sentido Radical.

E finalmente, o nono ponto vem falar de provações, confirmações, novas descobertas e posicionamentos. Interessante o termo provação. Faz parte da experiência a possibilidade de uma reversão (que James chamava de "conversão" também, embora conversão à não-religião). $\mathrm{O}$ que mais uma vez afirma que não se trata de uma experiência meramente cognitiva, nem meramente afetiva, mas integral, da pessoa como um todo.

Se quiséssemos condensar tudo isso em alguns poucos pontos, diríamos que:

1) A experiência religiosa é a experiência de uma relação com o absolutamente transcendente, vivida na trama da vida cotidiana da pessoa, e que tem dois polos: experiência de uma presença divina e experiência de uma resposta humana. 
2) Ela inclui a compreensão de seu significado enquanto religioso, e isso quer dizer que só é possível dar conta inteiramente dela a partir de seu interior.

3) Como seu objeto é algo extra-mundano, e ela ocorre inteiramente num contexto mundano, ela é vivida como experiência de uma integração do mundano com o divino, ou como experiência de uma outra dimensão do humano, necessária para compreendê-lo.

4) Ocorre no interior de um processo, onde a vida da pessoa se transforma no decorrer de uma relação dialógica com os acontecimentos, onde a própria experiência enquanto religiosa se confirma e se clarifica progressivamente. No decorrer desse processo, cuja origem exata é, às vezes, difícil de estabelecer com precisão, há momentos mais marcantes de experiência da presença transcendente ou da resposta humana de uma entrega confiante.

5) Dentre os efeitos da experiência religiosa na vida da pessoa, podemos destacar: uma certa paz interior ou leveza de vida, uma descoberta e valorização do humano e do natural, um envolvimento ativo com as coisas deste mundo a partir desta valorização, uma transfiguração do olhar permitindo compreender um sentido mais profundo no que acontece. Esses efeitos não são propriamente externos à experiência religiosa, mas, de certa forma, também fazem parte dela.

\section{3) Para uma continuação}

Os resultados de uma pesquisa de tipo qualitativo, sem perder o seu valor (relativo ao âmbito de seus dados), são sempre de tal natureza que possam se enriquecer com novas pesquisas, ou mesmo serem sucedidos por formulações mais adequadas a partir de novas pesquisas ou de novos contextos. Assim sendo, gostaria de indicar aqui algumas direções possíveis de desenvolvimentos nessa linha de investigação.
Seriam todas as experiências religiosas de mesmo tipo? Nossos resultados não estariam marcados por um tipo de experiência apesar dos esforços de abstração de uma estrutura mais geral? Mesmo levando em conta o fato de Lídia ter nos fornecido um depoimento particularmente rico, motivo pelo qual ele foi escolhido aqui, certamente seria preciso considerar outros depoimentos, variando o tipo de pessoas junto a quem eles seriam colhidos. Talvez a partir daí pudéssemos descrever "variedades de experiências religiosas" que viriam complementar bem a descrição de uma estrutura geral. Pensamos por exemplo em pessoas de idade diferente, de tradição religiosa diferente, condição sócio-cultural diferente. Com certeza isso poderia enriquecer os resultados deste estudo.

$\mathrm{O}$ caso de Lídia ainda sugere um outro ponto, de interesse grande para a psicologia clínica: verificar as conseqüências de uma experiência religiosa marcante sobre o equilíbrio de vida da pessoa. Ou, se quisermos assim nos expressar, os tipos de efeito psicológico de uma experiência religiosa ou de uma vida religiosa. É muito provável que este ponto pressuponha respostas à indagação anterior.

Para não nos alongarmos ainda mais, mencionarei apenas um último ponto. Existiria uma evolução religiosa ao longo do desenvolvimento humano? Lídia parece nos sugerir que sim. Como se expressaria a experiência religiosa em cada uma das idades do desenvolvimento? Que diferenças haveriam? E existe ainda uma questão que surge aqui imediatamente: o fato de ter havido uma experiência religiosa mais marcante afetaria a forma como a partir daí poderíamos descrever a posição da mesma pessoa diante da questão religiosá? Ou diante de outros dilemas do desenvolvimento humano? E aqui um contato com o estudo de Fowler (sobre os estágios do que ele chama de fé) (1992), seria fundamental. O projeto que estamos apresen- 
tando para mantermos viva essa linha de pesquisa aqui na PUC-Campinas, toma este terceiro caminho.

\section{Referências Bibliográficas}

Amatuzzi, Mauro M. (1997). A experiência religiosa: busca de uma definição. Estudos de Psicologia (no prelo).

Buber, Martin (1984). Eclipse de Dios - estudios sobre las relaciones entre Religión y Filosofia. Buenos Aires, Nueva Visión (as conferências originais são de 1951).

Buber, M.(1991). Encontro - Fragmentos Autobiográficos. Petrópolis/RJ, Vozes.

Ellwood, Robert S. (1994). "Religious Experience" and Socialization: A Response to David Hay. The International Journal for the Psychology of Religion, 4 (1):25-28.

Fowler, James W. (1992). Os Estágios da Fé - A Psicologia do Desenvolvimento Humano e a Busca de Sentido. São Leopoldo/RS: Sinodal. (Original americano, copyriht 1981).

Giorgi, Amedeo (1985). Sketch of a psychological phenomenological method. In: GIORGI, A. (ed.) (1985). Phenomenology and psychological research. Pittsburgh/PA: Duquesne University Press, 8-22.

Hay, David (1994). "The Biology of God": What is the Current Status of Hardy's Hypothesis? The International Journal for the Psychology of Religion, 4(1): 1-23.

James, William (1991). As Variedades da Experiência Religiosa. (Um estudo sobre a natureza humana). Trad.Octávio Mendes Cajado. S.Paulo, Ed.Cultrix (original americano de 1902).

Meslin, Michel (1993). A experiência humana do divino - fundamentos de uma antropologia religio$s a$. Petrópolis/RJ: Vozes. (Original francês, copyright de1988)

Muchielli, Alex (1991). Les méthodes qualitatives. Paris: P.U.F.
Tamminen, Kalevi (Univ.of Helsinki) (1994). Religious Experiences in Childhood and Adolescence: A Viewpoint of Religious Development Between the Ages of 7 and 20. The International Journal for the Psychology of Religion, 4(2): 61-85.

Tomka, Miklós (1997). A fragmentação do mundo das experiências na época moderna. Concilium, 271(3):11-27 [387-403].

Vaz, Henrique de Lima (1986). Escritos de Filosofia: problemas defronteira. S.Paulo, ed.Loyola. 